\title{
Association of Cumulatively Low or High Serum Calcium Levels with Mortality in Long-Term Hemodialysis Patients
}

\author{
Jessica E. Miller ${ }^{a, d}$ Csaba P. Kovesdy ${ }^{f}$ Keith C. Norris ${ }^{e}$ Rajnish Mehrotrab, c \\ Allen R. Nissenson $^{c, g}$ Joel D. Kopple ${ }^{b-d}$ Kamyar Kalantar-Zadeh ${ }^{\text {a-d }}$ \\ ${ }^{a}$ Harold Simmons Center for Kidney Disease Research and Epidemiology, ${ }^{b}$ Los Angeles Biomedical Research \\ Institute at Harbor-UCLA Medical Center, Torrance, Calif., ' David Geffen School of Medicine at UCLA,

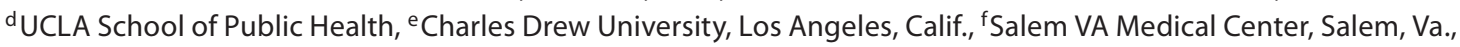 \\ and ${ }^{9}$ DaVita Inc., El Segundo, Calif., USA
}

\section{Key Words}

Hypocalcemia $\cdot$ Hypercalcemia $\cdot$ Phosphorus .

Hyperparathyroidism $\cdot$ Racial disparities $\cdot$ Mineral and

bone disorder $\cdot$ Chronic kidney disease $\cdot$ Paricalcitol

\begin{abstract}
Background:The outcome-predictability of baseline and instantaneously changing serum calcium in hemodialysis patients has been examined. We investigated the mortalitypredictability of time-averaged calcium values to reflect the 'cumulative' effect of calcium burden over time. Methods: We employed a Cox model using up-to-5-year (7/2001$6 / 2006$ ) time-averaged values to examine the mortality-predictability of cumulative serum calcium levels in 107,200 hemodialysis patients prior to the use of calcimimetics, but during the time where other calcium-lowering interventions, including lower dialysate calcium, were employed. Results: Both low $(<9.0 \mathrm{mg} / \mathrm{dl})$ and high $(>10.0 \mathrm{mg} / \mathrm{dl})$ calcium levels were associated with increased mortality (reference: 9.0 to $<9.5 \mathrm{mg} / \mathrm{dl}$ ). Whereas mortality of hypercalcemia was consistent, hypocalcemia mortality was most prominent with higher serum phosphorus ( $>3.5 \mathrm{mg} / \mathrm{dl}$ ) and PTH levels ( $>150$ $\mathrm{pg} / \mathrm{ml}$ ). Higher paricalcitol doses shifted the calcium range
\end{abstract}

\section{KARGER}

(C) 2010 S. Karger AG, Basel

Fax +4161306 1234 E-Mail karger@karger.ch www.karger.com www.karger.com/ajn associated with the greatest survival to the right, i.e. from 9.0 to $<9.5$ to 9.5 to $<10.0 \mathrm{mg} / \mathrm{dl}$. African-Americans exhibited the highest death hazard ratio of hypocalcemia $<8.5 \mathrm{mg} / \mathrm{dl}$, being 1.35 (95\% Cl: 1.22-1.49). Both a rise and drop in serum calcium over 6 months were associated with increased mortality compared to the stable group. Conclusions: Whereas in hemodialysis patients cumulatively high or low calcium levels are associated with higher death risk, subtle but meaningful interactions with phosphorus, PTH, paricalcitol dose and race exist.

Copyright $\odot 2010$ S. Karger AG, Basel

\section{Introduction}

In recent years, the observational studies indicating increased morbidity and mortality associated with high serum calcium levels among long-term hemodialysis (HD) patients have been well publicized, and the data have been assertively conveyed to the nephrology community $[1,2]$. However, most of these studies have examined short-term cohorts (1-3 years) or associations of baseline or instantaneously varying serum calcium with outcomes $[1,2]$. To our knowledge, none has examined 
the mortality of cumulatively high or low serum calcium levels as a long-term surrogate of circulating calcium burden or deficiency. Given the frequent occurrence of calcium disarrays in chronic kidney disease (CKD) patients [3], high degree of granularity of the recommended calcium target ranges by the guidelines (8.4-9.5 vs. 9.5-10.2 $\mathrm{mg} / \mathrm{dl})[4,5]$, racial disparities in bone and mineral disorders [6], and the close surveillance of outcome measures in dialysis patients in particular bone and mineral disorder surrogates [7], the outcomes associated with persistently high or low calcium levels across small calcium intervals (e.g. $0.5 \mathrm{mg} / \mathrm{dl}$ ) are of major clinical relevance. Whereas the hypercalcemia-death association has often been mentioned in recent CKD studies $[1,2,8,9]$, nonCKD literature describes serious complications including cardiovascular events associated with hypocalcemia [10]. In CKD patients, too, the results from several recent observational studies suggest a tendency towards increased death risk associated with hypocalcemia [2, 9, 11-14].

In recent years, there has been a tendency towards lower serum calcium levels in dialysis patients for the following reasons: (1) lowering dialysate fluid (bath) calcium concentrations from higher $(3.5 \mathrm{mEq} / \mathrm{l})$ to lower levels $(2.5,2.25$ or $2.0 \mathrm{mEq} / \mathrm{l})$; (2) use of calcimimetics; (3) switching from more calcemic active vitamin D (such as calcitriol) to less calcemic agents (such as paricalcitol [15] or maxacalcitol); (4) use of noncalcium-based binders; and (5) recommending lower dietary calcium intakes [7, 16-18]. The clinical outcomes of dialysis patients whose serum calcium is, on average, relatively low or high over a longer period of time is not clear. Heightened efforts to improve adherence to clinical practice guidelines to avoid 'high' serum calcium levels ( $>9.5 \mathrm{mg} / \mathrm{dl})$ to meet the socalled 'pay for performance' conditions may have led to practice patterns that lower calcium levels [7]. Hence, we revisited the mortality predictability of serum calcium, and in particular low calcium levels, over a longer period of time, i.e. up to 5 years, in a large (over 100,000 subjects) and contemporary (2001-2006) cohort of long-term HD patients prior to the widespread use of calcimimetics, but during the time where other calcium-lowering interventions, including lower dialysate calcium, were employed. We examined HD patients whose serum calcium and other laboratory values were measured monthly for up to 60 consecutive months in one single laboratory center (DaVita Lab). We hypothesized that both cumulatively high $(>10.0 \mathrm{mg} / \mathrm{dl})$ and low $(<9.0 \mathrm{mg} / \mathrm{dl})$ serum calcium levels are associated with an increased risk of death across diverse demographic and clinical categories of HD patients independent of race.

\section{Methods}

\section{Patients}

We extracted, refined and examined data from all individuals with CKD stage 5, who underwent HD treatment from July 2001 to June 2006, i.e. for 5 consecutive years, in one of the outpatient dialysis facilities large dialysis organization in the United States (DaVita prior to former Gambro acquisition). The study was approved by the institutional review committees of both the Los Angeles Biomedical Research Institute at Harbor-UCLA and DaVita Clinical Research.

\section{Clinical and Demographic Measures}

The creation of the cohort has been described previously [1923]. Demographic data such as race and marital status were derived from Form 2728 (Dialysis Initiation) [24]. To minimize measurement variability, all repeated measures for each patient during any given calendar quarter, i.e. over a 13-week or 3-month interval, were averaged and the quarterly means in each of the 20 calendar quarters were used in survival analyses. In addition to quarterly values, time-averaged (cumulative) values were calculated for up to 20 calendar quarters (q1-q20) for every laboratory and clinical measure evaluated for each patient over the 5 -year period, in that all monthly to quarterly values were averaged over the period. Dialysis vintage was defined as the duration of time between the 1st day of dialysis treatment and the 1st day that the patient entered the cohort. The 1st (baseline) study quarter for each patient was the calendar quarter in which the patient's vintage was $>45$ days during at least half of the time of that quarter.

\section{Laboratory Measures}

Blood samples were drawn using uniform techniques in all of the DaVita dialysis clinics and were transported to the DaVita laboratory in Deland, Florida, typically within $24 \mathrm{~h}$. All laboratory values were measured by automated and standardized methods. Most laboratory values were measured monthly except for serum ferritin and intact PTH, which were measured at least quarterly. Most blood samples were collected predialysis with the exception of the postdialysis serum urea nitrogen to calculate urea kinetics. The Kt/V (single pool) was calculated using urea kinetic modeling equations as described elsewhere [23]. Residual urea clearance was calculated from an interdialytic urine collection and the mean of pre- and postdialytic serum urea levels [25]. Albumin-corrected calcium was calculated by adding $0.8 \mathrm{mg} / \mathrm{dl}$ for each $\mathrm{g} / \mathrm{dl}$ serum albumin below $4.0 \mathrm{~g} / \mathrm{dl}$ [2].

\section{Administered In-Center Medications}

The average administered doses of injectable vitamin D receptor activators (VDRA) or erythropoietin-stimulating agents were calculated in each calendar quarter. Since over $90 \%$ of DaVita patients who received any VDRA between 2001 and 2006 received paricalcitol (Zemplar ${ }^{\mathrm{TM}}$; Abbott Laboratories, Abbott Park, Ill., USA), the dose of administered paricalcitol was calculated in $\mu \mathrm{g} /$ week for each calendar quarter and over the entire 5 years of the observation for each patient, and was included in the adjusted models. Patients who received any dose of paricalcitol were divided into tertiles of the averaged dose and examined separately (see below). For this study, data on oral medications including 
calcimimetics or phosphorus binders were not available. The calcimimetic cinacalcet became available in the United States during the last few months of this cohort $[26,27]$. Hence, the cohort is practically a precalcimimetic cohort.

\section{Statistical Methods}

We employed Cox proportional hazards regression using timeaveraged (up to 5 years) values. For each analysis, 3 models were examined based on the level of multivariate adjustment. The first was an unadjusted (or minimally adjusted) model that included mortality data and entry calendar quarter $(\mathrm{q} 1-\mathrm{q} 20)$. The second were case-mix adjusted models that included all of the above plus age, gender, race and ethnicity (African-Americans and other selfcategorized Blacks, Non-Hispanic Whites, Asians, Hispanics and others), diabetes mellitus, categories of dialysis vintage $(<6$ months, 6 months to 2 years, $2-5$ years and $\geq 5$ years), primary insurance [government-sponsored (Medicare, Medicaid), private and/or others), marital status (married, single, divorced, widowed or other/unknown), the standardized mortality ratio of the dialysis clinic during the entry quarter, residual renal function during the entry quarter, and Kt/V. Finally the third were malnutritioninflammation-cachexia syndrome (MICS)-adjusted models which included all of the covariates in the case-mix model as well as 11 indicators of nutritional status and inflammation, including body mass index (BMI), the normalized protein catabolic rate [22], and serum or blood concentrations of albumin, total iron-binding capacity, ferritin, creatinine, phosphorus, intact $\mathrm{PTH}$, bicarbonate, peripheral white blood cell count, lymphocyte percentage and hemoglobin. In our view, results from the unadjusted models are likely to be profoundly confounded due to omission of such potential confounders as age and gender, while results from the MICSadjusted models may be overadjusted due to possible inclusion of biological intermediates. We thus prefer to base inferences on the case-mix adjusted models. Because we cannot be certain of the best model, we have presented all 3 adjustment levels to provide the full spectrum of results.

Patients who were transplanted, switched to peritoneal dialysis or left the DaVita clinics were censored at the time of the event. Interaction terms based on the 3 strata (tertiles) of serum phosphorus and intact PTH and the prescribed dose of paricalcitol were included in additional analyses. Missing covariate data (under $1 \%$ for most laboratory and demographic variables) were imputed by the mean or median of the existing values. Most analyses were carried out with SAS, version 9.1 (SAS Institute Inc., Cary, North Carolina).

\section{Results}

The original 5-year (7/2001-6/2006) national database of all $\mathrm{DaVita} \mathrm{HD}$ patients included 152,058 adult subjects. After deleting those patients who did not maintain at least 45 days of HD treatment $(9,151$ patients from the first 19 calendar quarters and 3,579 patients from the last quarter), 139,328 HD patients remained. Out of the latter population, we identified $107,200 \mathrm{HD}$ patients in whom all quarterly serum calcium values and $90 \%$ or more of
Table 1. Clinical and laboratory values in all and 3 strata of 5 -year averaged corrected serum calcium levels in 107,200 maintenance HD patients

\begin{tabular}{|c|c|c|c|}
\hline & \multicolumn{3}{|c|}{ Serum calcium level } \\
\hline & $\begin{array}{l}<8.5 \\
(\mathrm{n}=3,848)\end{array}$ & $\begin{array}{l}8.5 \text { to }<10.2 \\
(\mathrm{n}=92,399)\end{array}$ & $\begin{array}{l}\geq 10.2 \\
(\mathrm{n}=10,953)\end{array}$ \\
\hline Patients, \% & 4 & 86 & 10 \\
\hline Age, years & $53.4 \pm 16.1$ & $61.6 \pm 15.4$ & $62.8 \pm 14.8$ \\
\hline Gender, \% women & 37 & 45 & 55 \\
\hline Diabetes mellitus, \% & 39 & 46 & 37 \\
\hline \multicolumn{4}{|l|}{ Race and ethnicity, \% } \\
\hline Caucasians & 32 & 42 & 39 \\
\hline Blacks & 37 & 32 & 41 \\
\hline Asians & 3 & 3 & 2 \\
\hline Hispanics & 18 & 16 & 9 \\
\hline \multicolumn{4}{|c|}{ Vintage (time on dialysis), $\%$} \\
\hline 3-6 months & 9 & 8 & 8 \\
\hline $6-24$ months & 29 & 34 & 23 \\
\hline $2-5$ years & 31 & 37 & 30 \\
\hline$>5$ years & 31 & 21 & 39 \\
\hline \multicolumn{4}{|l|}{ Primary insurance, $\%$} \\
\hline Medicaid & 9 & 6 & 4 \\
\hline \multicolumn{4}{|l|}{ Marital status, \% } \\
\hline Divorced & 8 & 7 & 7 \\
\hline Single & 35 & 22 & 22 \\
\hline Widowed & 8 & 12 & 15 \\
\hline BMI & $26.8 \pm 7.2$ & $26.9 \pm 6.9$ & $26.5 \pm 7.1$ \\
\hline nPCR (nPNA), g/kg/day & $1.01 \pm 0.27$ & $0.96 \pm 0.25$ & $0.94 \pm 0.25$ \\
\hline $\mathrm{Kt} / \mathrm{V}$ ( single pool) & $1.49 \pm 0.36$ & $1.53 \pm 0.35$ & $1.54 \pm 0.32$ \\
\hline Serum albumin, g/dl & $3.78 \pm 0.42$ & $3.70 \pm 0.44$ & $3.65 \pm 0.51$ \\
\hline Creatinine, mg/dl & $9.8 \pm 3.7$ & $8.1 \pm 3.3$ & $8.8 \pm 3.3$ \\
\hline Ferritin, ng/ml & $522 \pm 522$ & $510 \pm 470$ & $658 \pm 567$ \\
\hline Phosphorus & $6.6 \pm 2$ & $5.6 \pm 1.5$ & $5.6 \pm 1.4$ \\
\hline Calcium & $8.2 \pm 0.7$ & $9.4 \pm 0.5$ & $10.5 \pm 0.6$ \\
\hline Intact $\mathrm{PTH}^{*}$ & 348 & 268 & 343 \\
\hline & $(180-616)$ & $(152-482)$ & $(169-654)$ \\
\hline Bicarbonate & $21.1 \pm 3.3$ & $22.3 \pm 3.0$ & $22.9 \pm 3.1$ \\
\hline TIBC, mg/dl & $205 \pm 45$ & $209 \pm 45$ & $198 \pm 46$ \\
\hline $\mathrm{KRU}, \mathrm{ml} / \mathrm{min}$ & $0.36 \pm 1.27$ & $0.59 \pm 1.60$ & $0.28 \pm 1.05$ \\
\hline Blood hemoglobin, g/dl & $11.7 \pm 1.4$ & $12.0 \pm 1.3$ & $11.8 \pm 1.4$ \\
\hline WBC (per fl) & $7.1 \pm 2.6$ & $7.4 \pm 2.4$ & $7.6 \pm 2.6$ \\
\hline Lymphocyte, \% of WBC & $20.7 \pm 8.1$ & $20.7 \pm 7.9$ & $20.7 \pm 8.1$ \\
\hline
\end{tabular}

Values are percentages or means $\pm \mathrm{SD}$, as appropriate. ${ }^{*} \mathrm{Me}-$ dian value $(25-75 \%$ quartile). KRU $=$ Residual urea clearance; $\mathrm{nPNA}=$ normalized protein nitrogen appearance; $\mathrm{nPCR}=$ normalized protein catabolic rate; TIBC $=$ total iron binding capacity; $\mathrm{WBC}=$ white blood cell count

other monthly measured relevant laboratory values were available. These patients had a median cohort time of 582 days. Demographic and survival data among the 44,858 HD patients not included in this study were similar to the main cohort (data not shown). 
Fig. 1. Death hazard ratios (and 95\% CI) of 5-year averaged corrected serum calcium levels in 107,200 long-term HD patients (7/2001-6/2006).
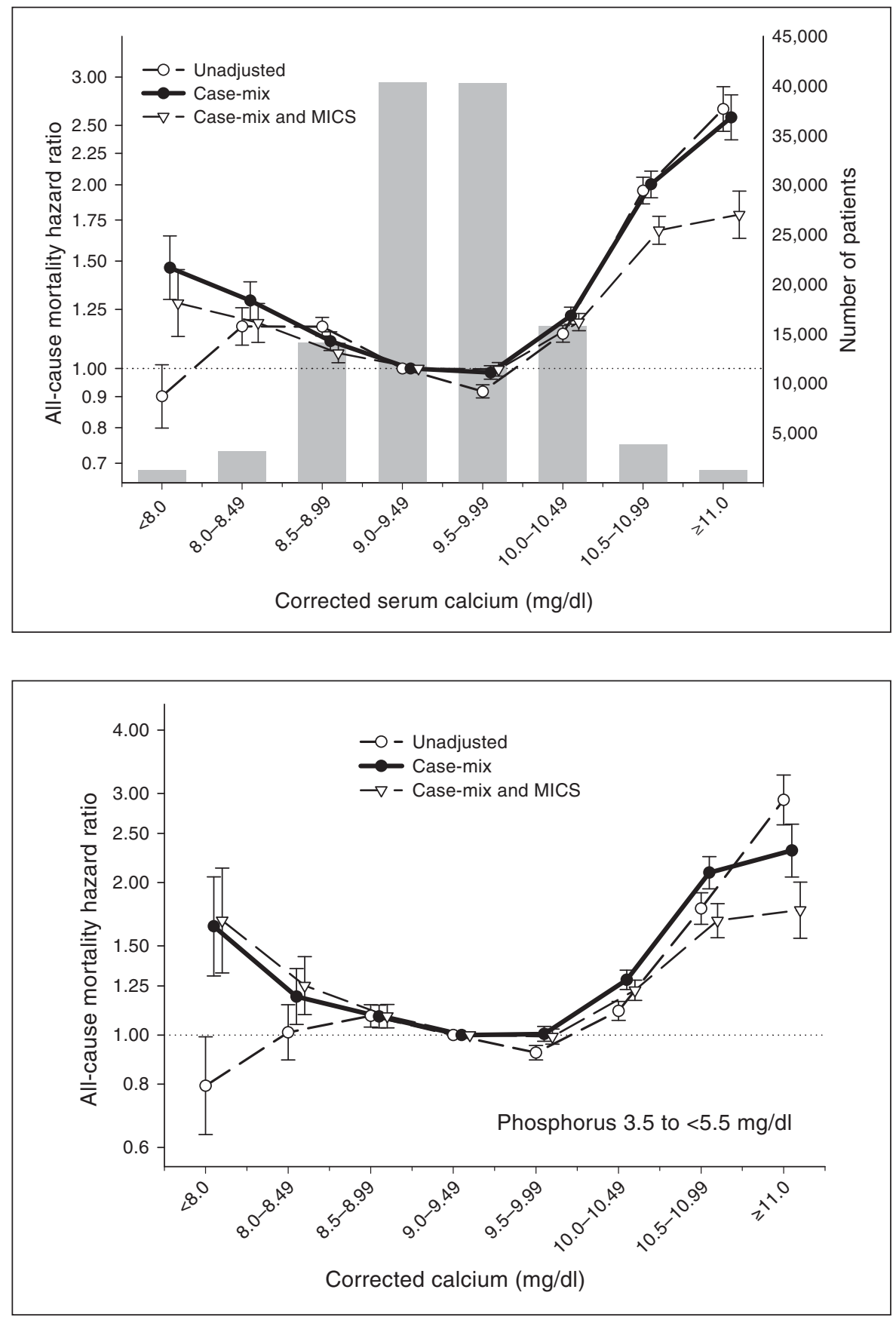

Fig. 2. Death hazard ratios (and 95\% CI) of 5 -year averaged corrected serum calcium levels in 107,200 long-term HD patients (7/2001-6/2006) across 3 strata of serum phosphorus.
We divided the 107,200 HD patients into 3 a priori selected serum calcium categories of $<8.5,8.5$ to $<10.2$, and $\geq 10.2 \mathrm{mg} / \mathrm{dl}$ to be similar to the suggested calcium levels of the Kidney Disease Outcome Quality Initiative (KDOQI) guidelines (table 1) [4]. As shown in table 1, $3.6 \%$ of patients maintained a time-averaged serum calcium $<8.5 \mathrm{mg} / \mathrm{dl}$. Comparing the latter hypocalcemic group with those with serum calcium $\geq 10.2 \mathrm{~g} / \mathrm{dl}$, the hy- pocalcemic patients had less women, more Hispanics and slightly higher serum phosphorus levels.

We divided the time-averaged corrected serum calcium values into 8 a priori selected groups of $<8.0 \mathrm{mg} / \mathrm{dl}$ and $\geq 11.0 \mathrm{mg} / \mathrm{dl}$ and 6 groups of $0.5 \mathrm{mg} / \mathrm{dl}$ increments in between. Cox regression calculated death hazard ratios of the calcium groups (reference group: serum calcium 9.0 to $<9.5 \mathrm{mg} / \mathrm{dl}$ ) are shown in figure 1 . The greatest sur- 
Fig. 3. Death hazard ratios (and 95\% CI) of 5 -year averaged corrected serum calcium levels in 107,200 long-term HD patients (7/2001-6/2006) across 3 strata of serum intact PTH.
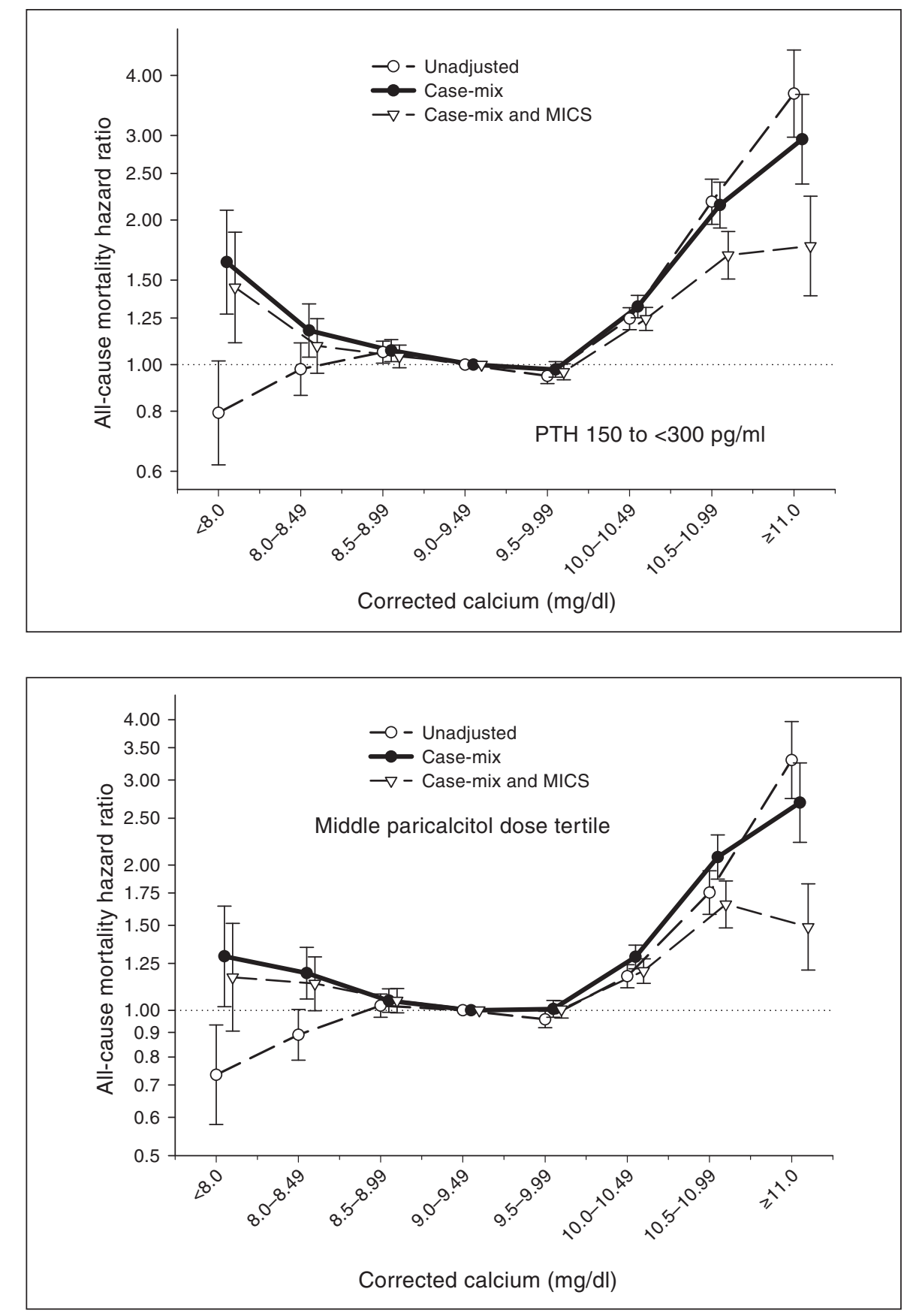

Corrected calcium (mg/dl)
Fig. 4. Death hazard ratios (and 95\% CI) of 5 -year averaged corrected serum calcium levels in 107,200 long-term HD patients (7/2001-6/2006) across 3 strata of administered paricalcitol. vival was associated with serum calcium in the 9.0-10.0 $\mathrm{mg} / \mathrm{dl}$ range. Both low $(<9.0 \mathrm{mg} / \mathrm{dl})$ and high calcium levels $(>10.0 \mathrm{mg} / \mathrm{dl})$ were associated with increased death risk relative to the reference group.

Given the statistical interactions found between serum calcium levels and other pertinent values including serum phosphorus and PTH levels and the administered VDRA dose and dialysate bath (data not shown), we fur- ther examined the mortality predictability of serum calcium within 3 strata (tertiles) of serum phosphorus $(<3.5$, $3.5-5.5$, and $\geq 5.5 \mathrm{mg} / \mathrm{dl})$ and PTH $(<150,150$ to $<300$, and $\geq 300 \mathrm{pg} / \mathrm{ml}$ ), consistent with the recommended KDOQI cutoff values, as well as tertiles of the administered paricalcitol doses, as shown in figures $2-4$. Figure 2 shows that in patients with low phosphorus patients $(<3.5 \mathrm{mg} / \mathrm{dl})$, where high calcium $>9.5 \mathrm{mg} / \mathrm{dl}$ was associ- 
Fig. 5. Death hazard ratios (and 95\% CI) of changes in serum calcium over the first 6 months in 107,200 long-term HD patients (7/2001-6/2006).

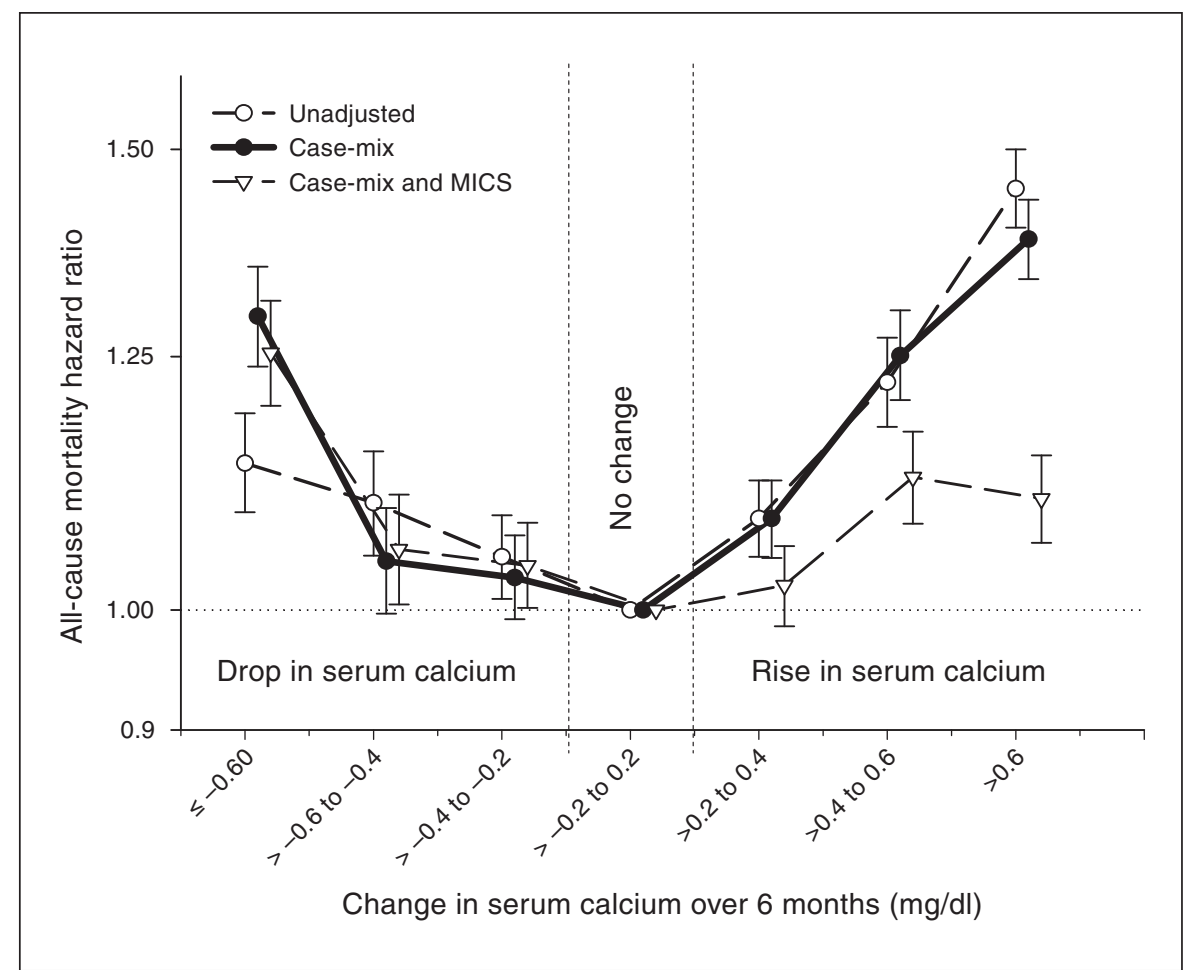

Table 2. Case-mix adjusted hazard ratios (and 95\% CI) of death for increments of up-to-5-year averaged serum calcium levels across 3 tertiles of administered paricalcitol dose in 107,200 maintenance HD patients between 7/2001 and 6/2006

\begin{tabular}{llll}
\hline $\begin{array}{l}\text { Time-averaged corrected } \\
\text { serum calcium, mg/dl }\end{array}$ & $\begin{array}{l}\text { Lowest paricalcitol tertile } \\
(\mathrm{n}=30,010)\end{array}$ & $\begin{array}{l}\text { Middle paricalcitol tertile } \\
(\mathrm{n}=36,824)\end{array}$ & $\begin{array}{l}\text { Highest paricalcitol tertile } \\
(\mathrm{n}=40,365)\end{array}$ \\
\hline$<8.0$ & $1.18(0.99-1.42)$ & $1.26(0.98-1.63)$ & $1.70(1.36-2.12)^{*}$ \\
8.0 to $<8.5$ & $1.08(0.95-1.23)$ & $1.17(1.03-1.33)^{*}$ & $1.43(1.26-1.61)^{*}$ \\
8.5 to $<9.0$ & $1.04(0.97-1.12)$ & $1.03(0.97-1.09)$ & $1.18(1.11-1.26)^{*}$ \\
9.0 to $<9.5$ (reference) & 1 & 1 & $0.92(0.88-0.96)^{*}$ \\
9.5 to $<10.0$ & $1.10(1.05-1.15)^{*}$ & $1.99(0.95-1.03)$ & $1.10(1.04-1.16)^{*}$ \\
10.0 to $<10.5$ & $1.31(1.23-1.40)^{*}$ & $2.07(1.86-2.31)^{*}$ & $1.96(1.82-2.11)^{*}$ \\
10.5 to $<11.0$ & $1.89(1.70-2.10)^{*}$ & $2.92(2.39-3.57)^{*}$ & $2.58(2.27-2.94)^{*}$ \\
$\geq 11.0$ & $3.03(2.61-3.52)^{*}$ & & \\
\hline
\end{tabular}

* Indicates a p value $<0.05$.

ated with increased mortality, low calcium $<9.0 \mathrm{mg} / \mathrm{dl}$ was not associated with an increased risk of death; however, in the upper 2 tertiles of serum phosphorus $(\geq 3.5$ $\mathrm{mg} / \mathrm{dl}$ ) a low calcium $<9.0$ showed incremental increase in mortality, while the greatest survival belonged to calcium in the $9.0-10.0 \mathrm{mg} / \mathrm{dl}$ range. A similar trend was observed across the tertiles of serum intact PTH (fig. 3). Across the increasing tertiles of the administered pari- calcitol dose (fig. 4 and table 2), a shift towards greater survival with higher calcium levels was noticed. Under the highest paricalcitol dose serum calcium $9.5-10.0 \mathrm{mg} /$ dl was associated with $9 \%$ better survival than the 9.0$9.5 \mathrm{mg} / \mathrm{dl}$ (reference), i.e. a death hazard ratio of 0.91 (95\% CI: 0.87-0.95). Calcium-mortality associations were similar across tertiles of dialysate calcium bath (data not shown). 
We also examined the association between changes in serum calcium over the first 6 months of the cohort and subsequent mortality. As shown in figure 5 , compared to HD patients whose serum calcium remained relatively stable $( \pm 0.2 \mathrm{mg} / \mathrm{dl}$ range), patients whose serum calcium dropped more than $0.6 \mathrm{mg} / \mathrm{dl}$ or increased more than 0.2 $\mathrm{mg} / \mathrm{dl}$ over 6 months showed an increase in death risk. Finally, we also compared the mortality-predictability of time-averaged low serum calcium $(<8.5 \mathrm{mg} / \mathrm{dl})$ to the reference $(8.5$ to $<10.2 \mathrm{mg} / \mathrm{dl})$ in the cohort. As shown in figure 6 , low calcium was associated with increased death risk in almost all subgroups of HD patients. In particular, African-Americans and those with longer dialysis vintage time or higher PTH levels showed increased death risk with hypocalcemia $<8.5 \mathrm{mg} / \mathrm{dl}$. In African-American HD patients, the death hazard ratio of hypocalcemia was 1.35 (95\% CI: 1.22-1.49).

\section{Discussion}

We studied the mortality-predictability of time-averaged serum calcium in 107,200 thrice-weekly HD patients in a large US dialysis organization from 2001 to 2006 , an era that preceded the widespread use of calcimimetics, but that included such calcium-lowering interventions as lower dialysate calcium concentrations and noncalcium-based phosphorus binders. We found that both low $(<9.0 \mathrm{mg} / \mathrm{dl})$ and high calcium levels ( $>10.0$ $\mathrm{mg} / \mathrm{dl}$ ) were associated with an increased risk of death when compared to the reference range of $9.0-9.5 \mathrm{mg} / \mathrm{dl}$. Whereas the association of hypercalcemia with mortality was rather consistent, the mortality-predictability of low calcium $<9.0 \mathrm{mg} / \mathrm{dl}$ was most prominent among those with higher serum phosphorus $(>3.5 \mathrm{mg} / \mathrm{dl})$ and PTH $(>150 \mathrm{pg} / \mathrm{ml})$. Higher doses of paricalcitol shifted the calcium range associated with the greatest survival to the right. African-Americans and those with longer dialysis vintage were more susceptible to the deleterious effect of low calcium $<8.5 \mathrm{mg} / \mathrm{dl}$. Both a rise and fall in serum calcium over 6 months were associated with an increased death risk. These findings may have important implications for the management of dialysis patients in an era where more emphasis is placed on lowering serum calcium based on data related to the death risk of hypercalcemia. Much less attention has been paid to the potential consequences of hypocalcemia, which seems to be on the rise in recent years, or interaction with other relevant conditions such as race, other laboratory values or the VDRA dose.

Calcium Level and Mortality
A rather persistent mortality-predictability of high serum calcium levels, usually above the $9.5-10.5 \mathrm{mg} / \mathrm{dl}$ range, has been reported in several recent epidemiologic studies in CKD populations [1, 2, 8, 9]. Since enhanced calcification of blood vessels, including coronaries, occurs often in CKD patients and is a strong death predictor [28], the hypercalcemia-death associations are often attributed to vascular calcification upon higher calcium load. The reported associations between high serum calcium levels and increased mortality, along with emerging data indicating a high prevalence of vascular calcification $[28,29]$, adynamic bone disease [30-32] and calciphylaxis [33] in CKD patients in the late 90s led to a quasi paradigm shift with recommendations for lower serum calcium levels.[4] To that end, the historical notion about the advantage of preventing negative calcium balance by using higher dialysate calcium concentrations $(3.5 \mathrm{mEq} / \mathrm{l})[34,35]$ was replaced with such calcium-lowering interventions as low dialysate calcium concentrations of $2.5 \mathrm{mEq} / \mathrm{l}$ or even lower; more frequent administration of calcimimetics, less calcemic active vitamin $\mathrm{D}$ agents $[17,36]$ and noncalcium-based phosphorus binders [37, 38]; and restricting dietary calcium levels [18]. As a result, lower serum calcium levels have been observed more frequently in recent years among dialysis patients [39]. However, the clinical outcomes of patients with lower serum calcium remained less clear. We found that cumulatively low calcium levels $<9.0 \mathrm{mg} / \mathrm{dl}$ are associated with increased death risk in most subgroups of HD patients. The contribution of the changes of serum calcium over time can be better examined using cumulatively averaged values over longer periods of time. In our study, the monthly measured serum calcium was averaged for up to 60 months, which is a unique strength of our study.

Maintenance of normal calcium balance and serum calcium concentrations is dependent upon a complex regulation of calcium absorption by the intestinal tract, excretion of calcium by the kidney when it is functional, and release of calcium from and deposition into the bone $[32,40]$. PTH increases serum calcium levels by stimulating bone resorption and renal distal tubular calcium reabsorption, and by promoting the conversion of 1- $\alpha$-hydroxylation of $25(\mathrm{OH}) \mathrm{D}_{3}$ to calcitriol $\left[1,25(0 \mathrm{H})_{2} \mathrm{D}_{3}\right]$ in the kidney $[41,42]$. In patients with CKD, the fraction of intestinal calcium absorption in the gastrointestinal tract is reduced because this process is vitamin $\mathrm{D}$-dependent and because CKD patients have reduced blood and tissue levels of calcitriol $[17,43]$. The CKD-associated hypocalcemia may be related to serious adverse outcomes, includ- 
ing worsening secondary hyperparathyroidism and bone demineralization that is common in CKD [44].

Calcium ions play a crucial role in excitation-contraction coupling in the myocardial cell, leading to enhanced automaticity and contractility in cardiac myocytes [45]. Thus, hypocalcemic states can precipitate such adverse cardiac events as cardiomyopathy, congestive heart failure, ventricular tachycardia and other arrhythmias [46, 47]. EKG findings in hypocalcemia include prolongation of the $\mathrm{QT}_{\mathrm{c}}$ interval, which may lead to torsades de pointes and ventricular fibrillation, and decreased $T$ wave voltage and negative T waves [48]. These events may result in sudden death, which is a common cause of mortality in HD patients [49]. Cramps, tetany, seizures and a host of other neurological complications may also occur in hypocalcemic states [46, 47].

There have been mixed data about the mortality-predictability of low serum calcium in CKD patients. Lowrie and Lew [11] were the first to report increased mortality with calcium $<9.0 \mathrm{mg} / \mathrm{dl}$ in over $12,000 \mathrm{HD}$ patients. In 1,846 prevalent HD patients, Wald et al. [12] reported that serum calcium levels below the KDOQI recommended target of $8.4-9.5 \mathrm{mg} / \mathrm{dl}$ were associated with increased mortality. In a cohort of 25,588 HD patients, Tentori et al. [13] reported that low baseline and time-dependent serum calcium levels $<8.5 \mathrm{mg} / \mathrm{dl}$ were associated with greater risk of all-cause mortality. Similar findings were reported by Kalantar-Zadeh et al. [2] in a 2-year cohort of $58,058 \mathrm{HD}$ patients, in whom serum calcium levels $<8.5$ $\mathrm{mg} / \mathrm{dl}$ (compared to $9.0-9.5 \mathrm{mg} / \mathrm{dl}$ ) were associated with increased death risk in time-dependent models. A similar trend, although not statistically significant, was reported by Melamed et al. [14]. However, Block et al. [1] did not find an increased mortality risk with hypocalcemia in 40,538 HD patients from the Fresenius dialysis clinics. Young et al. [50] found that serum calcium concentrations $<7.8 \mathrm{mg} / \mathrm{dl}$ were associated with lower mortality compared to $9.0-9.5 \mathrm{mg} / \mathrm{dl}$. Other deleterious outcomes can also be associated with hypocalcemia. Schwarz et al. [8] and Kovesdy et al. [9] found an association between low serum calcium levels and the higher rate of CKD progression and mortality. Noordzij et al. [51] reported a trend towards increased odds of muscle cramps in CKD patients with low calcium levels.

We found that a low serum calcium $<9.0 \mathrm{mg} / \mathrm{dl}$ was even more strongly associated with increased death risk among African-Americans (fig. 6). African-Americans have more severe secondary hyperparathyroidism and higher calcium levels [6]. Their higher susceptibility to the deleterious effect of hypocalcemia may be due to low-

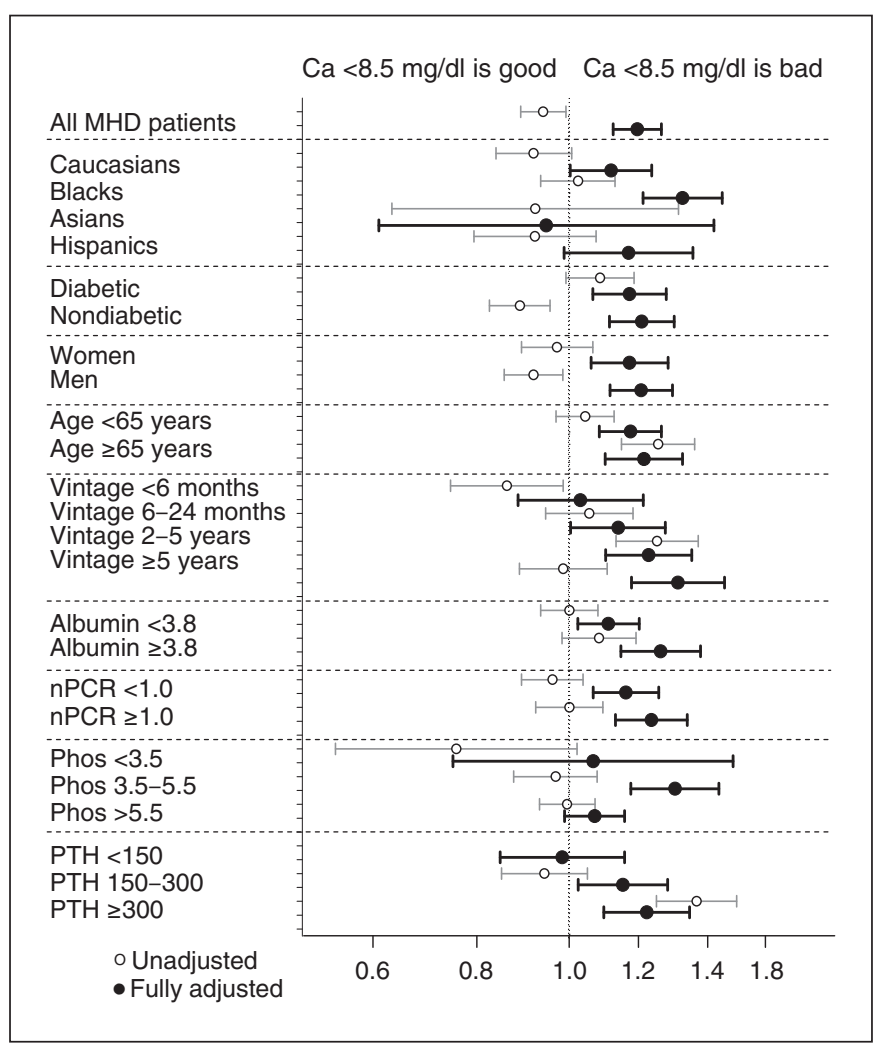

Fig. 6. Death hazard ratio of up-to-5-year averaged (albumin-corrected) serum calcium $<8.5 \mathrm{mg} / \mathrm{dl}$, compared to the reference range of 8.5 to $10.2 \mathrm{mg} / \mathrm{dl}$ in the cohort of 107,200 long-term HD patients (7/2001-6/2006).

er circulating vitamin D levels in African-Americans [6]. A similarly strong association was also found among HD patients who have been treated with dialysis for longer periods of time and those with higher serum PTH and phosphorus levels. It is possible that lower phosphorus levels (resulting from lower dietary phosphorus burden) $[52,53]$ or lower PTH levels (resulting from higher VRDA doses) $[15,54]$ mitigate the death risk in general, including in hypocalcemia. Lack of similar associations in other subgroups such as Asian HD patients may be related to statistical power rather than biological differences. Future studies are needed to verify these associations.

A limitation of our study is that we could not examine the factors that were associated with the different levels of serum calcium due to missing information concerning the types of phosphorus binders or the dietary sources of calcium. Our cohort belonged to the precalcimimetic era, and it could be argued that hypocalcemia as a result of calcimimetics may not be as deleterious. Never- 
theless, we consider it to be a unique strength of our study that our cohort was not contaminated by the calcium-lowering effects of calcimimetics, so that hypocalcemia could be examined with less confounding. Lower calcium levels may lead to worse survival by virtue of modulating the patient's nutritional and inflammatory status, so that MICS-adjusted models may be misleading due to overadjustment for these intermediates. If so, the case-mix adjusted models may be more appropriate. The strengths of our study include: (1) its contemporary nature since all patient data were obtained from the $21 \mathrm{st}$ century (2001-2006); (2) uniform laboratory measurements, with all laboratory data obtained from one single laboratory facility; (3) large sample size; (4) time-averaged $\mathrm{Kt} / \mathrm{V}$ and laboratory data of up to 60 monthly measurements; and (5) examining up to 5 years of data rather than shorter periods.

\section{Conclusions}

Among 107,200 HD patients whose serum calcium was measured monthly for up to 60 months (7/2001$6 / 2006$ ) in the precalcimimetic era, both low and high values of time-averaged serum calcium levels were associated with increased death risk. The mortality predictability of low serum calcium was particularly prominent among African-Americans and those with longer-term vintage and higher PTH values. Low serum phosphorus or PTH levels were associated with less obvious mortality predictability of hypocalcemia. Higher paricalcitol doses shifted the calcium range associated with the greatest survival to the right. Both a rise and drop in serum calcium over the first 6 months were associated with an in- creased death risk in the ensuing years. The implications of our findings for the management of CKD patients deserve further examination during the current era, where a trend toward a lowering of the serum calcium concentrations in dialysis patients has been occurring.

\section{Acknowledgements}

The selected components of this study were presented orally in form of abstracts during the American Society of Nephrology (ASN) annual conferences, November 1-6, 2007, in San Francisco, Calif., and November 2-7, 2008, Philadelphia, Pa. We thank Mr. Robert Lehn at DaVita Laboratories in Deland, Fla., Mr. Joe Weldon, from DaVita Informatics, for providing the national database, and Mr. Chris Rucker, Dr. Mahesh Krishnan, and Ms. Beth Bennett from DaVita Clinical Research for their continued support.

\section{Disclosure Statement}

The study was supported by Dr. Kalantar-Zadeh's research grants from the National Institute of Diabetes, Digestive and Kidney Disease of the National Institute of Health (R01 DK078106), American Heart Association grant (0655776Y) and investigatorinitiated research grants from Abbott and DaVita Clinical Research and a philanthropic grant from Mr. Harold Simmons.

A.R.N is an employee of DaVita. R.M. is the director of peritoneal dialysis at DaVita Harbor-UCLA/MFI in Torrance, Calif. K.K.-Z. is the medical director of DaVita Harbor-UCLA/MFI in Long Beach, Calif. K.C.N. and K.K.-Z. have received honoraria and/or grant funds from Abbott, the manufacturer of paricalcitol (Zemplar ${ }^{\mathrm{TM}}$ ). C.P.K. has received research grants from Abbott, Genzyme and Shire. Other authors have not declared any conflict of interest.

\section{References}

1 Block GA, Klassen PS, Lazarus JM, Ofsthun N, Lowrie EG, Chertow GM: Mineral metabolism, mortality, and morbidity in maintenance hemodialysis. J Am Soc Nephrol 2004; 15:2208-2218.

-2 Kalantar-Zadeh K, Kuwae N, Regidor DL, Kovesdy CP, Kilpatrick RD, Shinaberger CS, McAllister CJ, Budoff MJ, Salusky IB, Kopple JD: Survival predictability of time-varying indicators of bone disease in maintenance hemodialysis patients. Kidney Int 2006; 70 : 771-780.
3 Stevens LA, Li S, Wang C, Huang C, Becker BN, Bomback AS, Brown WW, Burrows NR, Jurkovitz CT, McFarlane SI, Norris KC, Shlipak M, Whaley-Connell AT, Chen SC, Bakris GL, McCullough PA: Prevalence of CKD and comorbid illness in elderly patients in the United States: results from the Kidney Early Evaluation Program (KEEP). Am J Kidney Dis 2010;55:S23-S33.

4 National Kidney Foundation I, Kidney Disease-Dialysis Outcome Quality Initiative: K/DOQI clinical practice guidelines for bone metabolism and disease in chronic kidney disease. Am J Kidney Dis 2003; 42:S1-S202.
5 Uhlig K, Berns JS, Kestenbaum B, Kumar R, Leonard MB, Martin KJ, Sprague SM, Goldfarb S: KDOQI US commentary on the 2009 KDIGO Clinical Practice Guideline for the Diagnosis, Evaluation, and Treatment of CKD-Mineral and Bone Disorder (CKDMBD). Am J Kidney Dis 2010;55:773-799.

6 Kalantar-Zadeh K, Miller JE, Kovesdy CP, Mehrotra R, Lukowski LR, Streja E, Ricks J, Jing J, Nissenson AR, Greenland S, Norris $\mathrm{KC}$ : Impact of race on hyperparathyroidism, mineral disarrays, administered vitamin $\mathrm{D}$ and survival in hemodialysis patients. J Bone Miner Res 2010, E-pub ahead of print. 
7 Kalantar-Zadeh K, Shah A, Duong U, Hechter RC, Dukkipati R, Kovesdy CP: Kidney bone disease and mortality in CKD: revisiting the role of vitamin $\mathrm{D}$, alkaline phosphatase and minerals. Kidney Int Suppl 2010, in press.

-8 Schwarz S, Trivedi BK, Kalantar-Zadeh K, Kovesdy CP: Association of disorders in mineral metabolism with progression of chronic kidney disease. Clin J Am Soc Neph 2006;1:825-831.

-9 Kovesdy CP, Kuchmak O, Lu JL, KalantarZadeh K: Outcomes associated with serum calcium level in men with non-dialysis-dependent chronic kidney disease. Clin J Am Soc Nephrol 2010;5:468-476.

10 Zivin JR, Gooley T, Zager RA, Ryan MJ: Hypocalcemia: a pervasive metabolic abnormality in the critically ill. Am J Kidney Dis 2001:37:689-698.

11 Lowrie EG, Lew NL: Death risk in hemodialysis patients: the predictive value of commonly measured variables and an evaluation of death rate differences between facilities. Am J Kidney Dis 1990;15:458-482.

12 Wald R, Sarnak MJ, Tighiouart H, Cheung AK, Levey AS, Eknoyan G, Miskulin DC: Disordered mineral metabolism in hemodialysis patients: an analysis of cumulative effects in the Hemodialysis (HEMO) Study. Am J Kidney Dis 2008;52:531-540.

-13 Tentori F, Blayney MJ, Albert JM, Gillespie BW, Kerr PG, Bommer J, Young EW, Akizawa T, Akiba T, Pisoni RL, Robinson BM, Port FK: Mortality risk for dialysis patients with different levels of serum calcium, phosphorus, and PTH: the Dialysis Outcomes and Practice Patterns Study (DOPPS). Am J Kidney Dis 2008;52:519-530.

- 14 Melamed ML, Eustace JA, Plantinga L, Jaar BG, Fink NE, Coresh J, Klag MJ, Powe NR: Changes in serum calcium, phosphate, and PTH and the risk of death in incident dialysis patients: a longitudinal study. Kidney Int 2006;70:351-357.

-15 Shinaberger CS, Kopple JD, Kovesdy CP, McAllister CJ, van Wyck D, Greenland S, Kalantar-Zadeh K: Ratio of paricalcitol dosage to serum parathyroid hormone level and survival in maintenance hemodialysis patients. Clin J Am Soc Nephrol 2008;3:17691776.

16 Mochizuki T, Naganuma S, Tanaka Y, Iwamoto Y, Ishiguro C, Kawashima Y, Maekawa K, Suda A, Akiba T: Prospective comparison of the effects of maxacalcitol and calcitriol in chronic hemodialysis patients with secondary hyperparathyroidism: a multicenter, randomized crossover study. Clin Nephrol 2007;67:12-19.

-17 Kalantar-Zadeh K, Kovesdy CP: Clinical outcomes with active versus nutritional vitamin D compounds in chronic kidney disease. Clin J Am Soc Nephrol 2009;4:15291539.
18 Kovesdy CP, Mehrotra R, Kalantar-Zadeh K: Battleground: chronic kidney disorders mineral and bone disease - calcium obsession, vitamin $\mathrm{D}$, and binder confusion. Clin J Am Soc Nephrol 2008;3:168-173.

19 Kalantar-Zadeh K, Lee GH, Miller JE, Streja E, Jing J, Robertson JA, Kovesdy CP: Predictors of hyporesponsiveness to erythropoiesis-stimulating agents in hemodialysis patients. Am J Kidney Dis 2009;53:823-834.

20 Kalantar-Zadeh K, Regidor DL, Kovesdy CP, Van Wyck D, Bunnapradist S, Horwich TB, Fonarow GC: Fluid retention is associated with cardiovascular mortality in patients undergoing long-term hemodialysis. Circulation 2009;119:671-679.

21 Regidor DL, Kovesdy CP, Mehrotra R, Rambod M, Jing J, McAllister CJ, Van Wyck D, Kopple JD, Kalantar-Zadeh K: Serum alkaline phosphatase predicts mortality among maintenance hemodialysis patients. J Am Soc Nephrol 2008; 19:2193-2203.

-22 Shinaberger CS, Greenland S, Kopple JD Van Wyck D, Mehrotra R, Kovesdy CP, Kalantar-Zadeh K: Is controlling phosphorus by decreasing dietary protein intake beneficial or harmful in persons with chronic kidney disease? Am J Clin Nutr 2008;88:15111518.

23 Miller JE, Kovesdy CP, Nissenson AR, Mehrotra R, Streja E, Van Wyck D, Greenland S, Kalantar-Zadeh K: Association of hemodialysis treatment time and dose with mortality and the role of race and sex. Am J Kidney Dis 2010;55:100-112.

24 Longenecker JC, Coresh J, Klag MJ, Levey AS, Martin AA, Fink NE, Powe NR: Validation of comorbid conditions on the end-stage renal disease medical evidence report: the CHOICE study. Choices for Healthy Outcomes in Caring for ESRD. J Am Soc Nephrol 2000;11:520-529.

25 McKane W, Chandna SM, Tattersall JE, Greenwood RN, Farrington K: Identical decline of residual renal function in high-flux biocompatible hemodialysis and CAPD. Kidney Int 2002;61:256-265.

26 Kalantar-Zadeh K, Kovesdy CP: Is it worth correcting hyperparathyroidism if hyperphosphatemia and hypocalcemia worsen? A cinacalcet story. Am J Kidney Dis 2009;53: 183-188.

27 Belozeroff V, Goodman WG, Ren L, Kalantar-Zadeh K: Cinacalcet lowers serum alkaline phosphatase in maintenance hemodialysis patients. Clin J Am Soc Nephrol 2009;4: 673-679.

28 Shantouf RS, Budoff MJ, Ahmadi N, Ghaffari A, Flores F, Gopal A, Noori N, Jing J, Kovesdy CP, Kalantar-Zadeh K: Total and individual coronary artery calcium scores as independent predictors of mortality in hemodialysis patients. Am J Nephrol 2010;31: 419-425.
29 Braun J, Oldendorf M, Moshage W, Heidler R, Zeitler E, Luft FC: Electron beam computed tomography in the evaluation of cardiac calcification in chronic dialysis patients. Am J Kidney Dis 1996;27:394-401.

30 Kurz P, Monier-Faugere MC, Bognar B, Werner E, Roth P, Vlachojannis J, Malluche HH: Evidence for abnormal calcium homeostasis in patients with adynamic bone disease. Kidney Int 1994;46:855-861.

- 31 Fournier A, Yverneau PH, Hue P, Said S, Hamdini N, Eldin HM, Mohageb S, Oprisiu R, Marie A, Solal ME, et al: Adynamic bone disease in patients with uremia. Curr Opin Nephrol Hypertens 1994;3:396-410.

-32 Andress DL: Adynamic bone in patients with chronic kidney disease. Kidney Int 2008; 73 : 1345-1354.

33 Bleyer AJ, Choi M, Igwemezie B, de la Torre E, White WL: A case control study of proximal calciphylaxis. Am J Kidney Dis 1998;32: 376-383.

34 Merrill JP, Hampers CL: Uremia. II. N Engl J Med 1970;282:1014-1021.

35 Collier VU, Mitch WE: Accelerated progression of chronic renal insufficiency after parathyroidectomy. JAMA 1980;244:12151218

36 Kovesdy CP: Survival benefits with vitamin D receptor activation: new insights since 2003. Clin J Am Soc Nephrol 2010, Epub ahead of print

37 Shantouf R, Budoff MJ, Ahmadi N, Tiano J, Flores F, Kalantar-Zadeh K: Effects of sevelamer and calcium-based phosphate binders on lipid and inflammatory markers in hemodialysis patients. Am J Nephrol 2008:28:275-279.

38 Shantouf R, Ahmadi N, Flores F, Tiano J, Gopal A, Kalantar-Zadeh K, Budoff MJ: Impact of phosphate binder type on coronary artery calcification in hemodialysis patients. Clin Nephrol 2010;74:12-18.

39 Andress DL: Lower target calcium levels in dialysis patients. Semin Dial 2002;15:74.

-40 Slatopolsky E, Gonzalez E, Martin K: Pathogenesis and treatment of renal osteodystrophy. Blood Purif 2003;21:318-326.

41 Kovesdy CP, Kalantar-Zadeh K: Vitamin D receptor activation and survival in chronic kidney disease. Kidney Int 2008;73:13551363.

42 Massry SG, Goldstein DA: Role of parathyroid hormone in uremic toxicity. Kidney Int Suppl 1978:S39-S42.

-43 Massry SG, Goldstein DA, Malluche HH: Current status of the use of 1,25(OH)2D3 in the management of renal osteodystrophy. Kidney Int 1980;18:409-418.

44 Park JC, Kovesdy CP, Duong U, Streja E, Rambod M, Nissenson AR, Sprague SM, Kalantar-Zadeh K: Association of serum alkaline phosphatase and bone mineral density in maintenance hemodialysis patients. Hemodial Int 2010;14:182-192. 
-45 Donovan PJ, Propp DA: Calcium and its role in cardiac arrest: understanding the controversy. J Emerg Med 1985;3:105-116.

-46 Chavan CB, Sharada K, Rao HB, Narsimhan $\mathrm{C}$ : Hypocalcemia as a cause of reversible cardiomyopathy with ventricular tachycardia. Ann Intern Med 2007; 146:541-542.

-47 Kazmi AS, Wall BM: Reversible congestive heart failure related to profound hypocalcemia secondary to hypoparathyroidism. Am J Med Sci 2007;333:226-229.

48 RuDusky BM: ECG abnormalities associated with hypocalcemia. Chest 2001;119:668669.

49 McCullough PA: Acute coronary syndromes in patients with renal failure. Curr Cardiol Rep 2003;5:266-270.
50 Young EW, Albert JM, Satayathum S, Goodkin DA, Pisoni RL, Akiba T, Akizawa T, Kurokawa K, Bommer J, Piera L, Port FK: Predictors and consequences of altered mineral metabolism: the Dialysis Outcomes and Practice Patterns Study. Kidney Int 2005;67: 1179-1187.

51 Noordzij M, Boeschoten EW, Bos WJ, Dekker FW, Bossuyt PM, Krediet RT, Korevaar JC: Disturbed mineral metabolism is associated with muscle and skin complaints in a prospective cohort of dialysis patients. Nephrol Dial Transplant 2007;22:29442949.

52 Noori N, Kalantar-Zadeh K, Kovesdy CP, Bross R, Benner D, Kopple JD: Association of dietary phosphorus intake and phosphorus to protein ratio with mortality in hemodialysis patients. Clin J Am Soc Nephrol 2010;5: 683-692.
53 Kalantar-Zadeh K, Gutekunst L, Mehrotra R, Kovesdy CP, Bross R, Shinaberger CS, Noori N, Hirschberg R, Benner D, Nissenson AR, Kopple JD: Understanding sources of dietary phosphorus in the treatment of patients with chronic kidney disease. Clin J Am Soc Nephrol 2010;5:519-530.

54 Dukkipati R, Kovesdy CP, Colman S, Budoff MJ, Nissenson AR, Sprague SM, Kopple JD, Kalantar-Zadeh K: Association of relatively low serum parathyroid hormone with malnutrition-inflammation complex and survival in maintenance hemodialysis patients. J Ren Nutr 2010;20:243-254. 